\title{
Developing Water Resources Within and Without Borders: Egypt's Road to Achieve Sustainable Development
}

\author{
Prof. Hossam Moghazy \\ Minister of Water Resources and Irrigation
}

Egypt is currently facing a significant challenge to strike a balance between the increasing demand of water and its available amounts; hence, the Egyptian Ministry of Water Resources and Irrigation has laid down a water policy that takes into consideration the present challenges and the future changes. To counter these challenges, this water policy is based on eight pivotal points as follows:

- Developing water resources within and outside borders in cooperation with the River Nile basin countries;

- Rationing water usage to make the best use of water resources;

- Improving water quality so as to protect the environment and citizens' general health;

- Supporting national projects and integrated development along with promoting investment and exports;

- Consolidating and rehabilitating facilities and water-lifting stations to guarantee optimal usage control, develop irrigation condition, and upgrade irrigation and drainage networks;

- Protecting coasts and facilities from climate changes and torrents threats; and

- Adopting the concept of water resources integrated management.

The Ministry of Water Resources and Irrigation strongly believes that developing water resources both within and outside borders is Egypt's road to achieve sustainable development, and therefore the Ministry adopts all scientific and executive measures to reach these goals for the welfare of Egyptian citizens.

I would like to thank the Renewable Energy and Sustainable Development Journal issued by the Arab Academy for Science, Technology and Maritime Transport Publishing House and to wish its board every success.

May God Almighty guide us towards the welfare of our beloved Egypt.

\footnotetext{
About Prof. Hossam Eldin Mohamed Murad Mughazy

Prof. Hossam Eldin assumed the portfolio of the Egyptian Ministry of Irrigation in September 2015. He got his baccalaureate with first grade of honours in 1982 and was granted his Master Degree in Science from the Faculty of Engineering, Alexandria University in 1985. In 1990, he obtained his PhD from the University of London, UK and Alex UNV on the topic: Optimal Well Design to Utilise Groundwater in Dry Areas.

Prof. Hossam Mughazy has been a professor of Irrigation and drainage Engineering since 2000 and held the position of the head of the Irrigation and Hydraulics Engineering Department at the Faculty of Engineering, Alexandria University in August 2010.

He has a lot of scientific publications and specialised articles published in a multiplicity of scientific periodicals and conferences in the fields of groundwater, irrigation and drainage engineering, as well as protecting the water environment. He has also supervised a lot of MSc theses and PhD dissertations in a number of Egyptian and Arab universities. Prof. Mughazy was awarded Alexandria University encouragement trophy in 1998.
} 